\title{
Spatio-temporal variability of sugarcane yield efficiency in the state of São Paulo, Brazil
}

\author{
Fabio Ricardo Marin ${ }^{(1)}$ and Gustavo Luís de Carvalho(2)
}

\begin{abstract}
(1)Embrapa Informática Agropecuária, Avenida André Tosello, № 209, Barão Geraldo, Caixa Postal 6041, CEP 13083-886 Campinas, SP, Brazil. E-mail: marin@cnptia.embrapa.br (2)Universidade de São Paulo, Escola Superior de Agricultura Luiz de Queiroz, Avenida Pádua Dias, oo 11, Caixa Postal 9, CEP 13418-900 Piracicaba, SP, Brazil. E-mail: gut006@hotmail.com
\end{abstract}

\begin{abstract}
The objective of this work was to assess the spatial and temporal variability of sugarcane yield efficiency and yield gap in the state of São Paulo, Brazil, throughout 16 growing seasons, considering climate and soil as main effects, and socioeconomic factors as complementary. An empirical model was used to assess potential and attainable yields, using climate data series from 37 weather stations. Soil effects were analyzed using the concept of production environments associated with a soil aptitude map for sugarcane. Crop yield efficiency increased from 0.42 to 0.58 in the analyzed period (1990/1991 to 2005/2006 crop seasons), and yield gap consequently decreased from 58 to $42 \%$. Climatic factors explained $43 \%$ of the variability of sugarcane yield efficiency, in the following order of importance: solar radiation, water deficit, maximum air temperature, precipitation, and minimum air temperature. Soil explained $15 \%$ of the variability, considering the average of all seasons. There was a change in the correlation pattern of climate and soil with yield efficiency after the 2001/2002 season, probably due to the crop expansion to the west of the state during the subsequent period. Socioeconomic, biotic and crop management factors together explain $42 \%$ of sugarcane yield efficiency in the state of São Paulo.
\end{abstract}

Index terms: actual yield, attainable yield, biofuel, socioeconomy, yield gap.

\section{Variabilidade espaço-temporal da eficiência produtiva da cana-de-açúcar no Estado de São Paulo}

Resumo - O objetivo deste trabalho foi analisar a variabilidade espacial e temporal da eficiência produtiva da cana-de-açúcar e o deficit de produtividade no Estado de São Paulo, ao longo de 16 safras agrícolas, tendo-se considerado o clima e o solo como efeitos principais e os aspectos socioeconômicos como efeitos complementares. Utilizou-se um modelo empírico para avaliar as produtividades potencial e atingível, tendose utilizado séries de dados climáticos de 37 estações meteorológicas. Os efeitos do solo foram analisados por meio do conceito de ambientes de produção associado a um mapa de aptidão dos solos para a cana-de-açúcar. A eficiência da produtividade aumentou de 0,42 a 0,58 no período avaliado (safras de 1990/1991 a 2005/2006), com consequente redução do deficit de produtividade de 58 para $42 \%$. Os fatores climáticos explicaram $43 \%$ da variabilidade da eficiência produtiva da cana-de-açúcar, na seguinte ordem de importância: radiação solar, deficiência hídrica, temperatura máxima do ar, precipitação e temperatura mínima do ar. O solo explicou 15\% da variabilidade, na média de todas as safras. Houve alteração no padrão de correlação do clima e do solo com a eficiência produtiva a partir da safra 2001/2002, provavelmente por causa da expansão da cultura para a região oeste do Estado, no período subsequente. Fatores socioeconômicos, bióticos e de manejo da cultura explicam, em conjunto, $42 \%$ da variabilidade na eficiência produtiva da cana-de-açucar, no Estado de São Paulo.

Termos para indexação: produtividade atual, produtividade atingível, biocombustível, socioeconomia, deficit de produtividade.

\section{Introduction}

Sugarcane is one of the world's major food-producing C4 crops, providing about $75 \%$ of the sugar harvested for human consumption (Souza et al., 2008), and is one of the most important crops for the Brazilian economy. It was introduced into Brazil in the $17^{\text {th }}$ century to break a world monopoly, and became socially important around the country (Canabrava, 2005). More recently, sugarcane has also become recognized as one of the central plant species for electricity and energy production, as liquid fuel (Goldemberg, 2007).

The concept of sugarcane yield efficiency (Marin et al., 2008) can be used as a quantitative index to: evaluate the development of farming systems in time and space, allowing the comparison of regions in relation to soil 
and weather conditions; assess farming techniques; compare time variation within a region; and to verify the effectiveness of new technologies and companies in that region. This analysis may be useful for policy and decision makers, in the private or public sector, to better understand the system and its spatial features, and to determine if and how the new technologies are introduced into the farming systems over time.

In spite of the huge progress Brazil has been made in the last 35 years in agricultural and industrial sectors, there is still room for improvement. Crop model simulations for potential yield compared to actual yield $-81 \mathrm{Mg} \mathrm{ha}^{-1}$ in the 2008/2009 season, according to Instituto Brasileiro de Geografia e Estatística (2002) - show that the sugarcane yield gap is still high. Yield gap analysis, in which attainable yields without nutrient and water limitations are compared with actual yields, can be used to identify the expected yield increase by alleviating these constraints (Booling et al., 2011).

The objective of this work was to assess the spatial and temporal variability of sugarcane yield efficiency and yield gap in the state of São Paulo, Brazil, throughout 16 growing seasons, considering climate and soil as main effects, and socioeconomic factors as complementary.

\section{Materials and Methods}

The weather data was supplied by the Sistema de Monitoramento Agrometeorológico (Agritempo, 2002), covering the period from 1990 to 2006. Climate series of 37 weather stations, located in the state of São Paulo, were organized in a ten-day time step. Daily solar radiation values were simulated according to Hargreaves \& Samani (1985), using the formula $\mathrm{RS}=\mathrm{Ra} \times \mathrm{Kt}(\mathrm{TM}-\mathrm{Tm})^{0.5}$, in which: Rs is the global solar radiation ( $\mathrm{MJ} \mathrm{m}^{-2}$ per day); $\mathrm{Ra}$ is the extraterrestrial solar radiation ( $\mathrm{MJ} \mathrm{m}^{-2}$ per day); $\mathrm{Kt}$ is an empirical coefficient $\left({ }^{\circ} \mathrm{C}^{-0.5}\right)$, being 0.16 for inland and 0.19 for coastal locations (Allen et al., 1998); and TM and Tm are the maximum and minimum air temperatures $\left({ }^{\circ} \mathrm{C}\right)$.

An empirical model, derived from Doorembos \& Kassan(1994), wasusedtoassess thepotentialyield(PY), represented by $\mathrm{PY}=-6.2501+0.2187 \mathrm{~S}+0.3304 \mathrm{~T}$ ( $\mathrm{Mg} \mathrm{ha}{ }^{-1}$ per ten days), in which: $\mathrm{T}$ is the mean air temperature $\left({ }^{\circ} \mathrm{C}\right)$ for ten days and $\mathrm{S}$ is the incident solar radiation $\left(\mathrm{MJ} \mathrm{m}^{-2}\right.$ per day). The attainable water-limited yield (WLY) was calculated according to Jensen (1968) as,
WLY/PY $=\left(\mathrm{ETa}_{1} / \mathrm{ETm}_{1}\right)^{\lambda_{1}}\left(\mathrm{ETa}_{2} / \mathrm{ETm}_{2}\right)^{\lambda_{2}}\left(\mathrm{ETa}_{3} / \mathrm{ETm}_{3}\right)^{\lambda_{3}}$,

in which: $\lambda_{1}=0.43, \lambda_{2}=0.39$, and $\lambda_{3}=0.07$ are water deficit sensibility coefficients for each of the three crop development stages: vegetative growth 1 , from planting to 180 days after planting (DAP); vegetative growth 2, up to 330 DAP; and 3, maturation, up to 360 DAP.

The actual crop evapotranspiration (ETa) was calculated for a ten-day time step, using a simple crop water-balance simulation (Thornthwaite \& Mather, 1955). The Kc coefficients and crop development stages used were described by Doorembos \& Kassan (1994) (Table 1), and the available soil water was determined according to Smith et al. (2005). Reference evapotranspiration (ETo) was estimated according to Camargo et al. (1999), modified from Thornthwaite (1948) to match with the Penman-Monteith method (Allen et al., 1998), using only air temperatures as input weather data. Crop coefficients were obtained according to Doorembos \& Kassan (1994), by assuming a 12-month growing cycle, and adjustments provided by Barbieri (1993).

Observed field data were used to parameterize the model, which well-compared $\left(\mathrm{R}^{2}=0.68\right)$ with the observed data, underestimating observed yields in 5.6\% (Carvalho, 2009). The parameterized model was used to estimate WLY, using adequate corrections for leaf area index, plant respiration, harvest index, and stalk moisture at harvest, as described by Carvalho (2009).

Simulations were made for three growing seasons (May to April, July to June, and October to September), representing the typical ratoon crop in early, middle and late growing seasons. The results from each year were averaged, and the average was used as a reference yield to calculate efficiency.

The soil map of São Paulo (Oliveira, 1999) was reclassified in order to get an aptitude soil map for sugarcane in the state (Figure 1). Four classes of soil aptitude for sugarcane (unsuitable, restrict, regular, and good aptitude) were assigned and then matched with yield depletion factors according to Prado (2005) - good aptitude

Table 1. Crop phase duration (days after planting, DAP), leaf area index (LAI), crop coefficients $(\mathrm{Kc})$, and water deficit sensibility coefficients $(\lambda)$.

\begin{tabular}{lcccc}
\hline Phase $^{(1)}$ & Duration (DAP) & LAI & $\mathrm{Kc}$ & $\lambda$ \\
\hline Vegetative growth 1 & 180 & 2.2 & 0.8 & 0.43 \\
Vegetative growth 2 & 330 & 5 & 1.2 & 0.39 \\
Maturation & 360 & 4 & 0.9 & 0.07 \\
\hline
\end{tabular}

(1) Jensen (1968) and Doorembos \& Kassan (1994). 
class, 1.00 as depletion factor; regular, 0.94; restrict, 0.84; and unsuitable aptitude, $0.74-$, in order to compute the genotype-environment interaction.

Using the raster calculator tool available in ArcGIS 9.3 (ESRI, Redlands, CA, USA), the aptitude soil map was multiplied by the WLY maps to produce a map of attainable soil and water limited yield (SWLY) for each growing season.

Actual sugarcane yield values (AY) for each county of the state of São Paulo, during the growing seasons of 1990/1991 and 2005/2006, were obtained from the Instituto Brasileiro de Geografia e Estatística (2006). Both AY and SWLY dataset were spatially organized and their maps were generated by the ordinary kriging interpolation tool from ArcGIS 9.3 (ESRI, Redlands, CA, USA), using a 900-m spatial resolution grid.

The raster calculator tool in ArcGIS 9.3 (ESRI, Redlands, CA, USA) was used to assess sugarcane yield efficiency (SYE) by dividing the AY maps by the SWLY maps, obtaining 16 efficiency yearly maps.

To quantify the soil and SYE relationship, soil aptitude classes were converted into a numerical rank from 1 to 4, and the Spearman correlation coefficient (SRC) (Snedecor \& Cochran, 1982) was applied. The Spearman correlation coefficient between SYE and soil was compared to the fertilizer consumed, in order to explore the effect of soil management on SYE.

Inorder to correlate efficiency with the others variables - air temperature, rainfall, water deficit and solar radiation -, the Pearson method (PC) was used (Snedecor \& Cochran, 1982). Socioeconomic and crop management (SEC) (varieties, diseases,

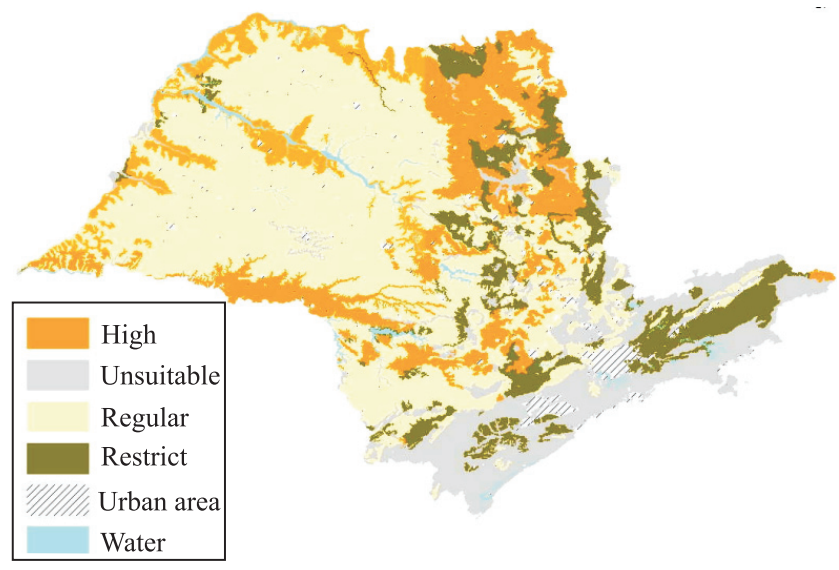

Figure 1. Aptitude soil map for sugarcane in the state of São Paulo, Brazil. pests etc.) influences on SYE were assumed to be the complementary value of the sum of the correlation indexes regarding soil and climate variables $(\mathrm{SEC}=1$ - SRC - PC). The yield gap (YG) was assumed to be the complementary value of SYE $(\mathrm{YG}=1$ - SYE).

\section{Results and Discussion}

The overall SYE average for the state of São Paulo was $48 \%$, increasing from 0.42 to 0.58 throughout the analyzed period. From 1990/1991 to $1995 / 1996$, SYE oscillated around 0.45, as a result of the tough Brazilian macroeconomic conjuncture and of the unfavorable conditions for sugar and ethanol commercialization (Goldemberg \& Lucon, 2007). Marin et al. (2008), using the Doorembos \& Kassan (1994) model, found values ranging from 0.38 to 0.43 .

Expressive yield increase occurred in the last six years of the evaluated period (Figure 2), which can be attributed to the increased ethanol consumption in Brazil. This was a result of the better gasoline-ethanol price ratio since the beginning of the 2000 s and of the availability of bi-fuel vehicles in Brazil after 2002 (Macedo, 2007).

In the analyzed period, the average sugarcane productivity of the state of São Paulo increased $12 \mathrm{Mg} \mathrm{ha}^{-1}$ (Figure 2). Therefore, the yield gap was reduced from 58 to $42 \%$ in the same period, possibly

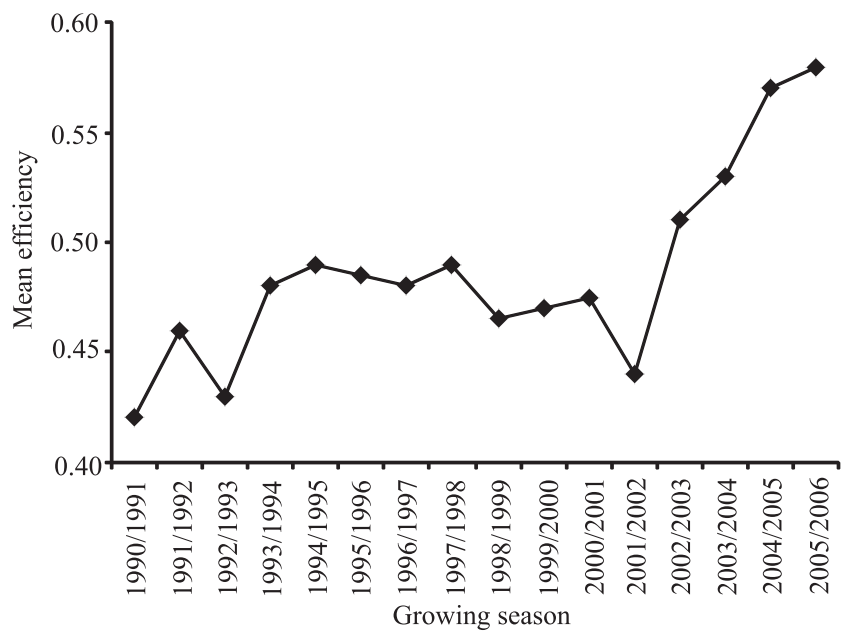

Figure 2. Sugarcane yield efficiency time variation in the state of São Paulo, Brazil, from the 1990/1991 to the 2005/2006 crop season. 
indicating the effect of investments, adoption of new technologies and of the expansion of new sugar mills in the west of the state.

Each increased SYE percentage point represents a yield increase of $0.8 \mathrm{Mg} \mathrm{ha}^{-1}$, which, extrapolated for the current sugarcane growing area in São Paulo, would represent an increase of two million megagrams of cane per SYE percentage point. This number has special importance when discussing the expansion of the Brazilian sugarcane growing area (Manzato et al., 2009), since, by driving new investments into the zones with higher SYE, less land would be needed to supply the Brazilian and international sugar and ethanol demands.

Low SYE areas $(<20 \%)$ were reduced by about $30 \%$ (Table 2, Figure $3 \mathrm{~B}$ and C), while high SYE areas $(>80 \%)$ showed greatest expansion over time (Table 2, Figure $4 \mathrm{D}$ and E). SYE had the highest increase rates in the northern and central regions of São Paulo State as a consequence of the new mills installed after 2000 (Figure 4).

Areas with a SYE higher than $80 \%$ expanded from 17,611 to $68,754 \mathrm{~km}^{2}$ (Table 2), indicating an intensification of land use in São Paulo and a new production pattern in sugarcane fields. In the traditional sugarcane growing areas, in which SYE is normally higher, this process may be a result of better crop management, mainly through varieties, fertilizers, and harvest management (Figure $4 \mathrm{C}, \mathrm{G}$ and $\mathrm{H}$ ).

In the newer areas, in which SYE is lower, the increase observed mostly after 2002 and the trend of

Table 2. Classes of sugarcane yield efficiency and occupied areas $\left(\mathrm{km}^{2}\right)$ in the state of São Paulo, Brazil, from $1990 / 1991$ to $2005 / 2006$.

\begin{tabular}{lccccc}
\hline Season & \multicolumn{5}{c}{ Efficiency class } \\
\cline { 2 - 6 } & $0-0.2$ & $0.2-0.4$ & $0.4-0.6$ & $0.6-0.8$ & $0.8-1.0$ \\
\hline $1990 / 1991$ & 74,369 & 31,141 & 60,006 & 65,083 & 17,611 \\
$1991 / 1992$ & 68,163 & 28,129 & 50,706 & 72,108 & 29,103 \\
$1992 / 1993$ & 75,092 & 32,060 & 48,556 & 76,701 & 15,801 \\
$1993 / 1994$ & 67,202 & 31,230 & 44,223 & 76,103 & 29,451 \\
$1994 / 1995$ & 65,013 & 29,030 & 42,757 & 67,343 & 44,066 \\
$1995 / 1996$ & 65,226 & 29,086 & 35,303 & 85,220 & 33,374 \\
$1996 / 1997$ & 67,059 & 26,558 & 37,199 & 86,557 & 30,836 \\
$1997 / 1998$ & 66,000 & 24,244 & 38,015 & 81,450 & 38,501 \\
$1998 / 1999$ & 67,847 & 23,441 & 47,039 & 90,020 & 19,862 \\
$1999 / 2000$ & 69,055 & 24,970 & 36,473 & 87,013 & 30,699 \\
$2000 / 2001$ & 76,600 & 25,011 & 31,311 & 72,275 & 43,012 \\
$2001 / 2002$ & 77,018 & 28,593 & 36,012 & 86,085 & 20,501 \\
$2002 / 2003$ & 66,247 & 23,059 & 39,253 & 80,225 & 39,425 \\
$2003 / 2004$ & 64,055 & 23,037 & 33,010 & 77,207 & 50,900 \\
$2004 / 2005$ & 60,851 & 19,050 & 23,628 & 79,900 & 64,780 \\
$2005 / 2006$ & 57,088 & 18,367 & 23,083 & 80,916 & 68,754 \\
\hline
\end{tabular}

rising SYE seem to be a consequence of replacing areas used for animal feeding and housing with commercial sugarcane (sugar mill-oriented), as sugar mills expanded to those regions and added an important land amount to the sugarcane production system.

Among the SYE drivers, climate accounted for $43 \%$ of the spatial variability of SYE, while soil explained $15 \%$ (varying from 10 to $18 \%$ ), as an overall average across spatial and time scales. Therefore, the soil plus climate-related factors accounted for $58 \%$ of the total SYE variability, and biotic, crop management and socioeconomic factors together comprised $42 \%$.

When separating climate into its components, by the average coefficient of determination $\left(\mathrm{R}^{2}\right)$ from $1990 / 1991$ to $2005 / 2006$, solar radiation $(0.16)$ was the most important factor, followed by water deficit (0.12), maximum air temperature (0.08), rainfall (0.06) and minimum air temperature (0.01). As observed by Marin et al. (2008), solar radiation had the highest determination coefficient variable $(16 \%)$, which may be due to the fact that most of the sugarcane growing areas have occupied some of the best agricultural areas of São Paulo, in which yield-limiting factors have less influence. Therefore, the crop was able to respond to a potential yield-related variable, such as solar radiation (Bowen \& Baethgen, 2002). In spite of the inclusion of new areas in the west of the state, this fact was only observed in the last few years, minimizing its impact on the analysis.

Water deficit accounted for $12 \%$ of the SYE variability, since rainfall amount and distribution seem to have been enough to ensure certain levels of sugarcane yield, even in the worst years during the analyzed period. Even in western São Paulo, in which the water deficit is usually higher than in the other regions of the state, sugarcane yield is still high, in comparison to Northeastern Brazil, where a dryer and hotter climate, in addition to poorer soils, resulted in average yield of $56 \mathrm{Mg} \mathrm{ha}^{-1}$ in the 2009/2010 season (Instituto Brasileiro de Geografia e Estatística, 2002). Therefore, due to the inclusion of data from that region in a similar study, a higher $\mathrm{R}^{2}$ would be expected regarding this variable, since water deficit plays a greater role.

The aggregation of climatic data into ten-day time steps reduces the time variability associated with climatic variables. In addition, as the analyses were based on a ten-day time-step average, part of the temporal variability was removed from the data, possibly reducing the influence of climate factors on SYE. The results obtained for rainfall and temperatures 

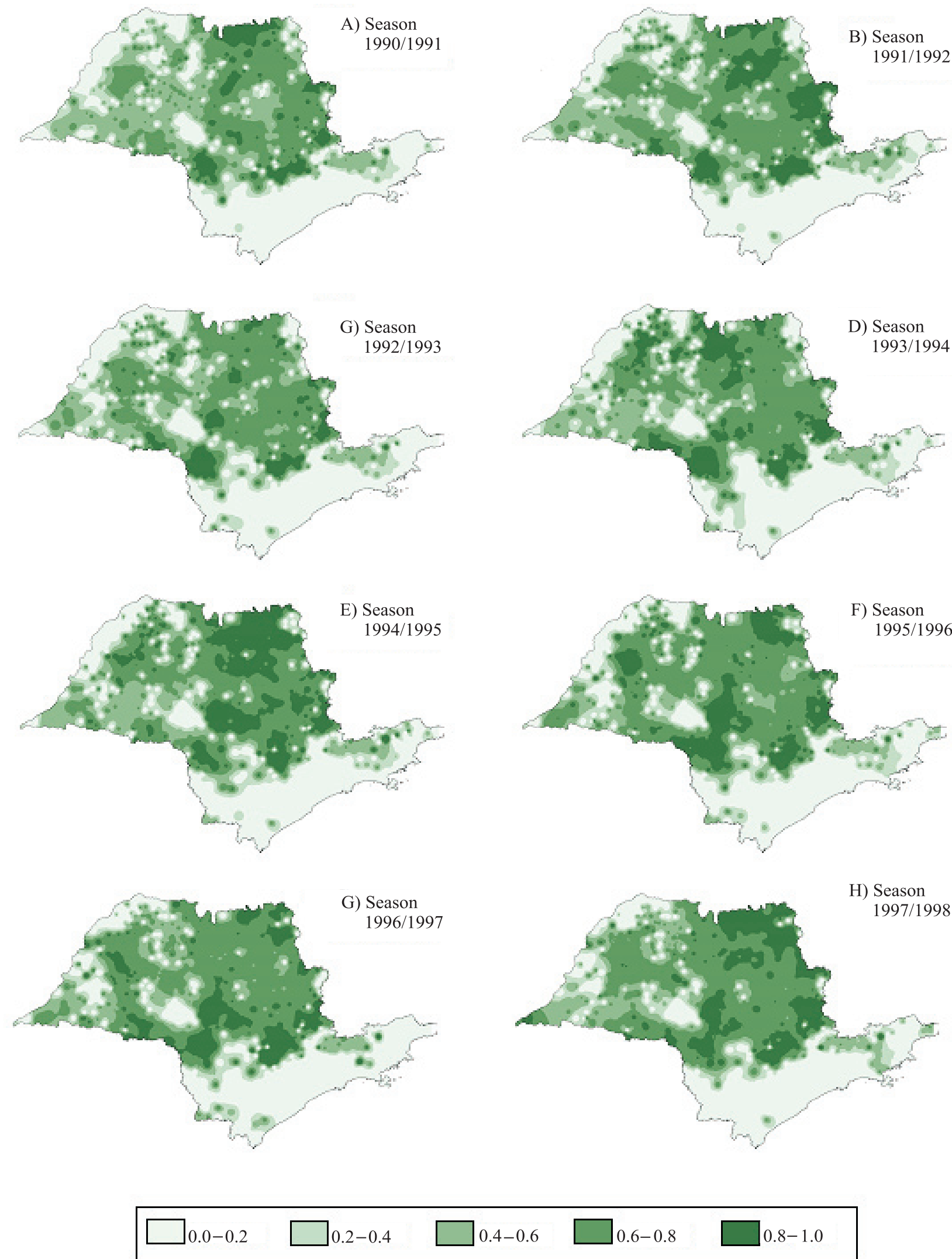

Figure 3. Sugarcane yield efficiency in the state of São Paulo, Brazil, from the 1990/1991 to the 1997/1998 crop season. 

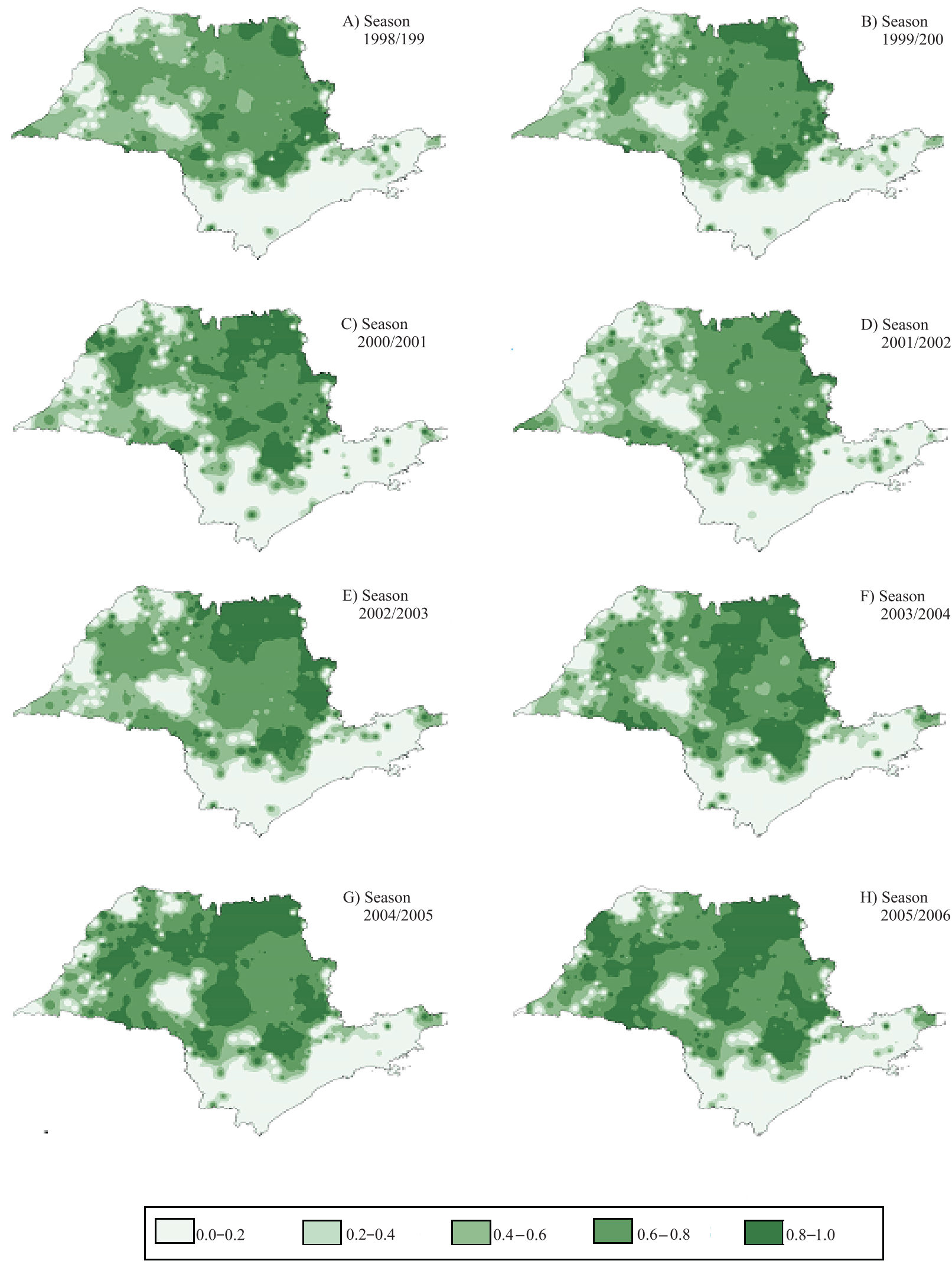

Figure 4. Sugarcane yield efficiency in the state of São Paulo, Brazil, from the 1998/1999 to the 2005/2006 crop season. 
also seem to be related with data aggregation, as most of the short-term time variation signals had been lost by averaging values in a ten-day time step. However, these results should be compensated due to the partial autocorrelation regarding climatic variables, since they were computed in the SWLY calculations

The remaining $42 \%$ of the SYE variability, accounting for the non-abiotic SYE drivers, may be time-related to public policies, prices, and costs. Management and genetic improvements are also included in this context, mainly expressed by an increasing yield trend.

Considering that the applied fertilizer and the Spearman index accounted for soil and SYE, it was hypothesized that seasons with tough economic conditions for growers should show a higher correlation between soil and SYE. However, when the economy is favorable to the sugarcane business, less correlation between soil and SYE is expected, since fertilizer application reduces the fertility deficiencies in poorer soils, masking soil spatial variability.

From 2002/2003 to2005/2006, fertilizer consumption and the Spearman correlation coefficient between SYE and soil increased (Figure 5), contradicting the stated hypothesis. A possible explanation is the intensive expansion of sugarcane growing areas to the west of the state of São Paulo, occupying less fertile soils than the traditional areas and, therefore, increasing the relative importance of soil in the SYE variability.

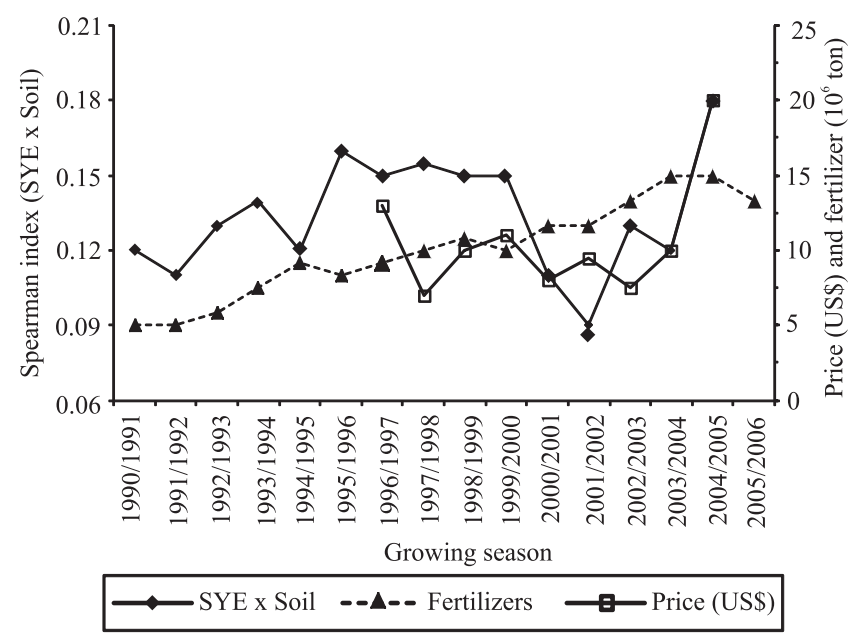

Figure 5. Sugar prices (US\$ per $50 \mathrm{~kg}$ ), amount of fertilizers sold in the central region of Brazil ( $10^{6}$ tons) (Ferreira \& Gonçalves, 2007), and average sugarcane yield efficiency in the state of São Paulo, Brazil.
Assuming that the previous hypothesis is correct, it is expected that the SYE-soil correlation will fall in the coming years, since the soil fertility of those new areas would be gradually improved over time, as observed after 2004 (Figure 4).

Since 2004, the average yield observed in the state was $50 \mathrm{Mg} \mathrm{ha}^{-1}$ spread over a wider area of São Paulo. The average attainable yield was $93 \mathrm{Mg} \mathrm{ha}^{-1}$; therefore, SYE was 0.54 in 2003/2004, 0.56 in 2004/2005 and 0.57 during the $2005 / 2006$ growing season. The increase in SYE seems to be related to sugar price, which rose from US\$ 11.3 per $50 \mathrm{~kg}$ to US\$ 20 per $50 \mathrm{~kg}$ in one year (Figure 5). The sugar price-SYE relationship analysis resulted in $\mathrm{R}^{2}=0.53$, showing a relatively high influence of commodity prices to explain the SYE variation. Consequently, sugar prices are self-correlated with climate variables in Brazil, since the country is the world's largest producer.

\section{Conclusions}

1. Climatic factors account for $43 \%$ of the variability of sugarcane yield efficiency, in the following order of importance: solar radiation, water deficit, maximum air temperature, precipitation, and minimum air temperature.

2. Soil explains $15 \%$ of the variability of sugarcane yield efficiency, with a pattern change after the 2001/2002 season, probably due to the crop expansion to the west of the state of São Paulo.

3 . Socioeconomic, biotic and crop management factors together explain $42 \%$ of sugarcane yield efficiency in the state of São Paulo.

\section{Acknowledgements}

To Conselho Nacional de Desenvolvimento Científico e Tecnológico, for financial support.

\section{References}

AGRITEMPO: sistema de monitoramento agrometeorológico. Campinas: Embrapa Informática Agropecuária; Campinas: Centro de Pesquisas Meteorológicas e Climáticas Aplicadas à Agricultura, 2002. Disponível em: <http://www.agritempo.gov.br>. Acesso em: 25 out. 2011.

ALLEN, R.G.; PEREIRA, L.S.; RAES, D.; SMITH, M. Crop evapotranspiration: guidelines for computing crop water requirements. Rome: FAO, 1998. (FAO. Irrigation and drainage paper, 56). 
BARBIERI, V. Condicionamento climático da produtividade potencial da cana-de-açúcar (Saccharum spp.): um modelo matemático-fisiológico de estimativa. 1993. 142p. Tese (Doutorado)Escola Superior de Agricultura Luiz de Queiroz, Piracicaba.

BOOLING, A.A.; BOUMAN, B.A.M.; TUONG, T.P.; KONBOON, D.; HARNPICHITVITAYA, D. Yield gap analysis and the effect of nitrogen and water on photoperiod-sensitive Jasmine rice in north-east Thailand. Wageningen Journal of Life Sciences, v.58, p.11-19, 2011.

BOWEN, W.T.; BAETHGEN, W.E. Simulation as a tool for improving nitrogen management. In: TSUJI, G.Y.; HOOGENBOOOM, G.; THORNTON, P.K. (Ed.). Understanding options for agricultural production. Dordrecht: Kluwer Academic, 2002. p.189-204.

CAMARGO, A.P. de; MARIN, F.R.; SENTELHAS, P.C.; PICINI, A.G. Ajuste da equação de Thornthwaite para estimar a evapotranspiração potencial em climas áridos e superúmidos, com base na amplitude térmica. Revista Brasileira de Agrometeorologia, v.7, p.251-257, 1999.

CANABRAVA, A.P. História econômica: estudos e pesquisas. São Paulo: UNESP, 2005. 320p.

CARVALHO, G.L. Eficiência da produção agrícola de cana-de-açúcar no Estado de São Paulo entre as safras 1990/1991 e 2005/2006. 2009. 118p. Dissertação (Mestrado) - Escola Superior de Agricultura Luiz de Queiroz, Piracicaba.

DOOREMBOS, J.; KASSAN, A.H. Efeitos da água no rendimento das culturas. Roma: FAO, 1994. 212p. (Estudos FAO: irrigação e drenagem, 33).

FERREIRA, R.; GONÇALVES, J.S. Evolução e sazonalidade do consumo de fertilizantes no Brasil e nas unidades da federação no período 1987-2005. Informações Econômicas, v.37, p.7-14, 2007.

GOLDEMBERG, J. Ethanol for a sustainable energy future. Science, v.315, p.808-810, 2007.

GOLDEMBERG, J.; LUCON, O. Energia e meio ambiente no Brasil. Estudos Avançados, v.21, p.7-20, 2007.

HARGREAVES, G.H.; SAMANI, Z.A. Estimating potential evapotranspiration. Journal of the Irrigation and Drainage Division, v.108, p.225-230, 1982.

INSTITUTO BRASILEIRO DE GEOGRAFIA E ESTATÍSTICA. Produção agrícola municipal. 2002. Disponível em: <http:// www.ibge.gov.br/home/estatistica/economia/pam/>. Acesso em: 30 out. 2011.

INSTITUTO BRASILEIRO DE GEOGRAFIA E ESTATÍSTICA. Produção agrícola municipal. 2006. Disponível em: $<$ http://www. ibge.gov.br/home/estatistica/economia/pam/2002/default.shtm>. Acesso em: 30 jun. 2011.

JENSEN, M.E. Water consumptions by agricultural plant growth. New York: Academic, 1968. v.2, 22p.

MACEDO, I.C. Situação atual e perspectivas do etanol. Estudos Avançados, v.21, p.157-165, 2007.

MANZATO, C.; ASSAD, E.D.; BACA, J.F.M.; ZARONI, M.J.; PEREIRA, S.E.M. (Org.). Zoneamento agroecológico da cana-de-açúcar: expandir a produção, preservar a vida, garantir o futuro. Rio de Janeiro: Embrapa Solos, 2009. 55p. (Embrapa Solos. Documentos, 110).

MARIN, F.R.; LOPES-ASSAD, M.L.; ASSAD, E.D.; VIAN, C.E.; SANTOS, M.C. Sugarcane crop efficiency in two growing seasons in São Paulo State, Brazil. Pesquisa Agropecuária Brasileira, v.43, p.1449-1455, 2008.

OLIVEIRA, J.B. de; CAMARGO, M.N.; ROSSI, M.; CALDERANO FILHO, B. Mapa pedológico do Estado de São Paulo: legenda expandida. Campinas: Instituto Agronômico; Rio de Janeiro: Embrapa Solos, 1999. 64p.

PRADO, H. Ambientes de produção da cana-de-açúcar na Região Centro-Sul do Brasil. Informações Agronômicas, n.110, p.6-9, 2005.

SMITH, D.M.; INMAN-BAMBER, N.G.; THORBURN, P.J. Growth and function of the sugarcane root system. Field Crop Research, v.92, p.169-183, 2005.

SOUZA, A.P. de; GASPAR, M.; SILVA, E.A. da; ULIAN, E.C.; WACLAWOVSKY, A.J.; NISHIYAMA JUNIOR, M.Y.; SANTOS, R.V. dos; TEIXEIRA, M.M.; SOUZA, G.M.; BUCKERIDGE, M.S. Elevated $\mathrm{CO} 2$ increases photosynthesis, biomass and productivity, and modifies gene expression in sugarcane. Plant, Cell and Environment v.31, p.1116-1127, 2008.

SNEDECOR, G.W.; COCHRAN, W.G. Statistical methods. $7^{\text {th }}$ ed. Ames: Iowa State University, 1982. 507p.

THORNTHWAITE, C.W.An approach toward a rational classification of climate. Geographical Review, v.38, p.55-94, 1948.

THORNTHWAITE, C.W.; MATHER, J.R. The water balance. New Jersey: Drexel Institute of Technology, 1955. 104p. (Publications in climatology, 8). 